\title{
Gebelik ile İlişkili Anksiyete Ölçeği: Türkçe Geçerlilik ve Güvenirlik Çalışması
}

\section{Pregnancy-related Anxiety Scale (The PrAS): Validity and Reliability Study of its Turkish Version}

\author{
Ayça Solt Kırca ${ }^{1}$, Derya Kanza Gül ${ }^{2}$ \\ ${ }^{1}$ Kirklareli University School of Health, Midwifery Depertmant, Kirklareli, Turkey. \\ ${ }^{2}$ Medipol University School of Medicine Health, Istanbul, Turkey. \\ e-mail: aycasolt@hotmail.com,deryakanza@yahoo.com \\ ORCID: 0000-0001-6733-5348 \\ ORCID: 0000-0001-8879-9299 \\ *Sorumlu yazar/ Corresponding Author: Ayça Solt Kırca \\ Gönderim Tarihi / Received: 25.06.2020 \\ Kabul Tarihi / Accepted: 14.10.2020 \\ DOI: $10.34087 /$ cbusbed.757864
}

Öz

Giriş ve Amaç: Kadınların hamilelik sırasında endişeleri olabilir. Bu kaygı hem kadınlar hem de bebekleri için olumsuz sonuçlara neden olabilir. Hamilelik sırasında ortaya çıkan bu kaygıyı psikometrik olarak belirlemek için bir ölçek gereklidir. $\mathrm{Bu}$ çalışma, Türk toplumunda PrAS'ın güvenilirlik ve geçerlilik çalışmasını yürütmeyi amaçlamaktadır.

Gereç ve Yöntemler: Çalışma metodolojik olarak tasarlanmıştır. Çalışmanın verileri İstanbul'da bulunan özel bir hastanenin Kadın Hastalıkları Polikliniğinde toplandı. Katılımcılar 495 gebeden (primiparous ve multiparous) oluştu. Bulgular: PrAS'ın Türkçe versiyonunun iç tutarlılı̆̆ $($ Cronbach's alpha = 0.85), maddelerin korelasyon katsayısı $(0.27$ ve 0.57$)$ ve doğrulayıcı faktör analizi (CFA $=0.35$ ve 0.98 ) yüksek bulunmuştur. Pras'ın PRAQ-R2 ile yüksek korelasyonu vardı (çok sayıda gebe kadın $r=0.60$, ilkel gebe kadın $r=0.65, p=0.000$ )

Sonuç: PrAS'ın Türkçe versiyonunun gebelik sırasında yaşanan kaygı düzeyini değerlendirmek için güvenilir ve geçerli bir araç olduğu gösterilmiştir ve bu araç diğer dillere kolayca uyarlanabilir.

Anahtar kelimeler: Anksiyete, Ebe, Gebelik, Geçerlik, Güvenirlik, Hemşirelik, Türkçeye uyum

\section{Abstract}

Objective: Women may have anxiety during pregnancy. This anxiety may have adverse results both for women and their infants. A scale is needed to determine this anxiety, that occurs during pregnancy, psychometrically. This study aims to conduct the reliability and validity study of the PrAS in Turkish population.

Materials and Methods: The study was designed methodologically. The data of the study were collected in the Obstetrics Outpatient clinic of a private hospital located in Istanbul. The participants were composed of 495 pregnant women (primiparous and multiparous).

Results: The internal consistency of the Turkish version of the PrAS (Cronbach's alpha $=0.85$ ), the correlation coefficient of the items $(0.27$ and 0.57$)$ and the confirmatory factor analysis $(\mathrm{CFA}=0.35$ and 0.98$)$ were found to be high. The PrAS had a high correlation with PRAQ-R2 (multiparous pregnant women $\mathrm{r}=0.60$, primiparous pregnant women $\mathrm{r}=0.65, \mathrm{p}=0.000$ )

Conclusion: It was demonstrated that the Turkish version of the PrAS was a reliable and valid instrument to assess the anxiety level experienced during pregnancy and this instrument may be easily adapted to other languages.

Keywords: Anxiety, Midwife, Nursing, Pregnancy, Reliability, Turkish adaptation, Validity.

\section{Introduction}

Pregnancy period is an important process in which woman have different spiritual, physical, and emotional experiences in her life. When a woman experiences this process, she may face with many factors that may affect their mental health such as stress, anxiety, depression, 
etc. [1-4]. When the literature is examined, it has been reported that approximately $10 \%$ to $24 \%$ of the pregnant women experience anxiety or stress during their pregnancy [5-8]. It has been stated based on the 2008 data of WHO that the prevalence of anxiety during pregnancy is $90 \%$ in the countries with high-income and $10 \%$ in the countries with low-income [9].

It is stated that a high level of anxiety experienced during pregnancy differs from woman to woman and based on the number of pregnancy (primiparous or multiparous) $[10,11]$. Failure to diagnose anxiety during pregnancy or treat anxiety causes negative results both for mothers (fetal health concern, fear of miscarriage, labor pain, postpartum depression) [12-14] and for infants (low birth weight, early labor, postnatal behavioral problems of children, weak cognitive development, autism, schizophrenia) [5, 15-18]. However, according to the results of the studies, it has been reported that the anxiety diagnosis and treatment rates are quite low during pregnancy $[19,20]$.

As the anxiety in pregnancy may have negative effects on the health of mothers and newborns especially in the natal and postnatal period, it is quite important to diagnose it in the early period of pregnancy [5, 18,21-4]. Screening in the early period will provide enough time to treat pregnancy-related anxiety [21]. Early diagnosis, prevention and good management of pregnancy-related anxiety will help women to develop strategies to cope with challenges caused by pregnancy-related anxiety [19]. Although pregnancy-related anxiety varies due to regional, individual and cultural characteristics, this anxiety is a universal phenomenon for all pregnant women all over the world [19]. Therefore, it is important to develop valid and reliable scales to determine pregnancy-related anxiety levels and to find out whether these scales are suitable for different social and cultural structures [3,10,19]. For this reason, the Pregnancyrelated Anxiety Scale (PrAS) which is a likert-type scale with 33 items, was developed by Brunton et al., in 2018 [22].

Having a scale to assess the anxiety in pregnancy from all aspects is emphasized as the best measure in terms of protecting the woman and infant health. This study aims to adapt "The Pregnancy-related Anxiety Scale (PrAS)" determining the anxiety in pregnancy into Turkish and to conduct its reliability and validity study.

\section{Materials and Methods}

\subsection{Design and participants}

Of the women who presented to the obstetric outpatient clinic of a private hospital in Istanbul, a major city in Turkey that straddles Europe and Asia across the Bosporus, between December 2018 and May 2019 for prenatal control in their 1st, 2nd and 3rd trimesters, those who had no psychiatric illnesses or depressive symptoms, no communication problems, and were primary school, high school or university graduates comprised the study population. In order for the factor analysis to be reliable in adapting a scale to a different culture, the sample size (the number of participants) should be five- to ten-fold the number of the items in the scale [23,24]. The study data were collected from 495 pregnant women selected by using the random sampling method. The face-to-face interview technique was used for data collection.

\subsection{Data Collection Instruments}

\subsubsection{Descriptive Characteristics Form}

This form, developed by the researchers in line with the pertinent literature, contains items questioning the participating pregnant women's socio-demographic characteristics such as age, occupation, educational status, economic status, and obstetric characteristics such as gestational age and parity.

2.2.2. The Pregnancy-Related Anxiety QuestionnaireRevised2 (PRAQ-R2)

The PRAQ-R2 was developed by Van den Bergh (1990) as a 5-point likert scale to determine the anxiety level to be experienced by all women during pregnancy period independently of parity [7].

Responses are rated on a 5-point scale ranging from (strongly agree) to (strongly disagree). The minimum and maximum possible scores to be obtained from the scale are 11 and 55 respectively for the group including the primiparae, 10 and 50 respectively for the group including the multiparae. The Cronbach's alpha reliability value of the scale changes according to different gestational weeks (the multiparous group: 0.71 to 0.85 and the primiparous group: 0.75 to 0.84 ) [7]. Its reliability and validity study in Turkey was conducted by Derya et al., in 2018. The Alpha value of the scale was found to be 0.61 to 0.82 for the multiparous group and 0.55 to 0.83 primiparous group [25].

2.2.3.The Pregnancy-related Anxiety Scale (PrAS)

The PrAS is a 4-point likert scale developed by Brunton et al., (2018) to assess the pregnancy-related anxiety. Responses range from "Absolutely I agree" to "I strongly disagree" (1-4). Eleven items have been reversed on the scale. The minimum score is 33 and the maximum score is 132 for the overall scale. High scores signify that pregnancy-related anxiety has increased. The scale has nine subscales. These are Childbirth Concerns (6 questions), Body image concerns (5 questions), Attitudes Towards childbirth (3 questions), Worry About Motherhood (3 questions), Acceptance of Pregnancy (3 questions), Anxiety indicators (4 questions), Attitudes Towards Medical Staff (3 questions), Avoidance and Baby Concerns (6 questions) [22]. The Alpha value of the scale is 0.77 to 0.95 . In the literature, no other studies testing the reliability and validity of The Pregnancyrelated Anxiety Scale were found.

\subsubsection{Translation of the PrAS}

The permission to translate the scale into Turkish was obtained from Robyn Brunton, the author of the scale. 1. At the language validity stage, the scale was translated from English to Turkish separately by the researchers. 2 . The scale was then translated back to English by a translator with a good command of English. 3. Then, the researchers compared and discussed the translations, and finally decided which statements were the best ones to use in the scale. 4 . In this stage, the scale was examined by the experts. 6 experts, who were fluent in both 
languages assessed the scale in terms of clarity of the expressions, intercultural comprehensibility and language consistency. The content validity indices (CVI) of all the items included in the scale for the expert opinions were found to be 1.00 in terms of relevancy, 0.99 in terms of simplicity assessment and 0.97 in terms of comprehensibility. Also, the intraclass coefficient correlation (two-way random effect, consistency model) (ICC) was found to be 0.75 for simplicity and 0.80 for comprehensibility (p:0.000, p<.001). In relationship assessment, ICC value could not be calculated as the scores of all the experts were the same [26]. 5. During this stage, the required revisions were performed based on the expert opinions and the Turkish version of the scale took its final form. 6 . This stage, it was translated into its original language by a professional translator who was not an expert in this field in order to obtain the semantic equivalence of the scale [27,28]. 7. Finally, the pilot scheme of PrAS arranged according to the expert advice was performed with 50 pregnant women and these results were not included in the study. During this application, none of the statements included in the scale were misunderstood. Thus, the Turkish version of the PrAS was completed.

\subsubsection{Validity}

Confirmatory factor analysis (CFA) was performed to test the construct validity of the scale. In the literature, the path coefficients demonstrating the relationship of the items with their subscale are load equal to factor load and they are recommended to be at least 0.30 and higher [29$31]$. In this study, CFA was found to be between 0.35 and 0.98 .

The goodness of fit statistics is required to be at the desired level in confirmatory factor analysis. NonNormed Fit Index (NNFI), Root Mean Square Error of Approximation (RMSEA), Adjusted Goodness of Fit Index (AGFI), Standardized Root-mean-Square Residual (SRMR), Comparative Fit Index (CFI) and Goodness of Fit Index (GFI) are among the frequently used goodness of fit tests. RMSEA of $\leq 0.80$ and $p<0.05$, SRMR of $<0.10$ (2), AGFI of $\geq 0.80$ and GFI of $\geq 0.85$, and CFI and NNFI of $\geq 0.90$ are the indicator of an acceptable fit. When these values are 0.95 and higher, they are an indicator of a perfect fit $[29,31,32]$.

To determine the validity of parallel forms, the scale is administered in one or two sessions to the same group together with another equivalent scale. This reliability coefficient also provides data on the concurrent validity of the scale. For this purpose, the PRAQ-R2 was used. The correlation between the PrAS and The PRAQ-R2 scales were calculated using the Pearson productmoment correlation analysis.

\subsubsection{Reliability}

In examining the reliability of likert type scales alpha internal consistency coefficient is used commonly. In order to accept the assessment instrument as reliable, its reliability coefficient must be close to 1 as much as possible. The closer the reliability coefficient to 1 is the more reliable the measurement tool is. If Alpha coefficient is less than 0.40 , it is accepted as insufficient; if it is between 0.40 and 0.59 , it is accepted as reliable; if it is between 0.60 and 0.79 , it is accepted as pretty reliable; if it is between 0.80 and 1.00 , it is accepted as very reliable $[33,34]$.

The level of item-total score correlations is an important criterion in item selection or assessing item suitability. Although the level of competence of the item-total score correlation coefficients varies based on the sources, the most accepted value is 0.25 . As the correlation coefficient becomes higher, item reliability is better [29]. 2.3.Data analysis

SPSS 16.0 for Windows (SPSS Inc., Chicago, IL, USA) was used to analyze the data of the study and the psychometric properties of the PrAS. In the study, number, percentage, mean and standard deviation were used for the descriptive statistics of the scale scores. The compliance of the numeric data to the normal distribution was assessed with Skewness (between -.50 and 1.63) and Kurtosis (between -.90 and 2.0) and it was found that the data had a normal distribution. The statistical significance level was accepted as $\mathrm{p}<.05$ [35].

\section{Results}

It was found that $78.4 \%$ of the pregnant women were aged between 19-32 years and $43 \%$ of them were overweight. $39.6 \%$ of the pregnant women were university graduates, $65.7 \%$ of them were unemployed, and $77.2 \%$ of them had a balanced income and expense level. $57.6 \%$ of the sample group was composed of primiparous pregnant women and $42.4 \%$ were composed of multiparous pregnant women. Based on the gestational week, $31.9 \%$ of the women were in the 1 st trimester, $33.3 \%$ were in the 2 nd trimester, and $34.7 \%$ were in the 3rd trimester. It was determined that the pregnancy of $94.3 \%$ of these pregnant women was planned, $98.4 \%$ had regular pregnancy controls, and $60 \%$ of them knew the gender of their infants (Table 1).

\subsection{Validity}

In the Turkish adaptation study of Pregnancy-Related Anxiety Scale, CFA loads of all the items were found to be between 0.35 and 0.98 . According to the result of the Chi-square fit statistics, which is among the CFA fit statistics, it was determined that the scale structure of the PrAS with 33 items was an acceptable model. Based on RMSEA (0.048), SRMR (0.053), CFI (0.96), NNFI (0.96), AGFI (0.87), and GFI (0.89) values obtained in this scale adaptation study, it was determined that the factor fit of the Turkish form of the PrAS was perfect (Fig. 1, Table 2). 
Table 1. The Descriptive and Obstetric Characteristics of the Pregnant Women (n: 495)

\begin{tabular}{|c|c|c|}
\hline Characteristics & $\mathbf{n}$ & $\%$ \\
\hline \multicolumn{3}{|l|}{ Age Group } \\
\hline 19-32 years & 388 & 78.4 \\
\hline $33-45$ years & 107 & 21.6 \\
\hline \multicolumn{3}{|l|}{ BMI } \\
\hline Slim-Normal & 197 & 39.8 \\
\hline Overweight & 213 & 43.0 \\
\hline Obese/Morbid obese ${ }^{* *}$ & 85 & 17.2 \\
\hline \multicolumn{3}{|l|}{ Educational Status } \\
\hline$\leq$ Primary education & 118 & 23.8 \\
\hline High school & 181 & 36.6 \\
\hline$\geq$ University & 196 & 39.6 \\
\hline \multicolumn{3}{|l|}{ Working status } \\
\hline Employed & 170 & 34.3 \\
\hline Unemployed & 325 & 65.7 \\
\hline \multicolumn{3}{|l|}{ Assessing the income status } \\
\hline The Income is lower than the expenses & 52 & 10.5 \\
\hline The income is equal to the expenses & 382 & 77.2 \\
\hline The income is higher than the expenses & 61 & 12.3 \\
\hline \multicolumn{3}{|l|}{ Parity } \\
\hline Primiparous & 285 & 57.6 \\
\hline Multiparous & 210 & 42.4 \\
\hline \multicolumn{3}{|l|}{ Trimester } \\
\hline $1^{\text {st }}$ trimester & 158 & 31.9 \\
\hline $2^{\text {nd }}$ trimester & 165 & 33.3 \\
\hline $3^{\text {rd }}$ trimester & 172 & 34.7 \\
\hline \multicolumn{3}{|l|}{ Planned pregnancy } \\
\hline Yes & 467 & 94.3 \\
\hline No & 28 & 5.7 \\
\hline \multicolumn{3}{|l|}{ Having controls in pregnancy } \\
\hline Yes & 487 & 98.4 \\
\hline No & 8 & 1.6 \\
\hline \multicolumn{3}{|l|}{ Knowing the gender of the infant } \\
\hline Yes & 297 & 60.0 \\
\hline No & 198 & 40.0 \\
\hline
\end{tabular}

In BMI groups*: 6 people are slim, ${ }^{* *}: 1$ person is morbid obese

Table 2. Fit Values of Confirmatory Factor Analysis of Pregnancy-Related Anxiety Scale (n: 495)

\section{CFA Fit Statistics}

Chi-square / $\mathrm{p}$ value

Degree of Freedom

Chi-square value: degree of freedom

RMSEA / p

SRMR

CFI

NNFI

GFI

AGFI
Fit Values

$$
\begin{gathered}
979.85 / .000(\mathrm{p}<.05) \\
454 \\
979.85: 454=2.16 \\
.048(\mathrm{p}<.05) \\
.053 \\
.96 \\
.96 \\
.89 \\
.87
\end{gathered}
$$




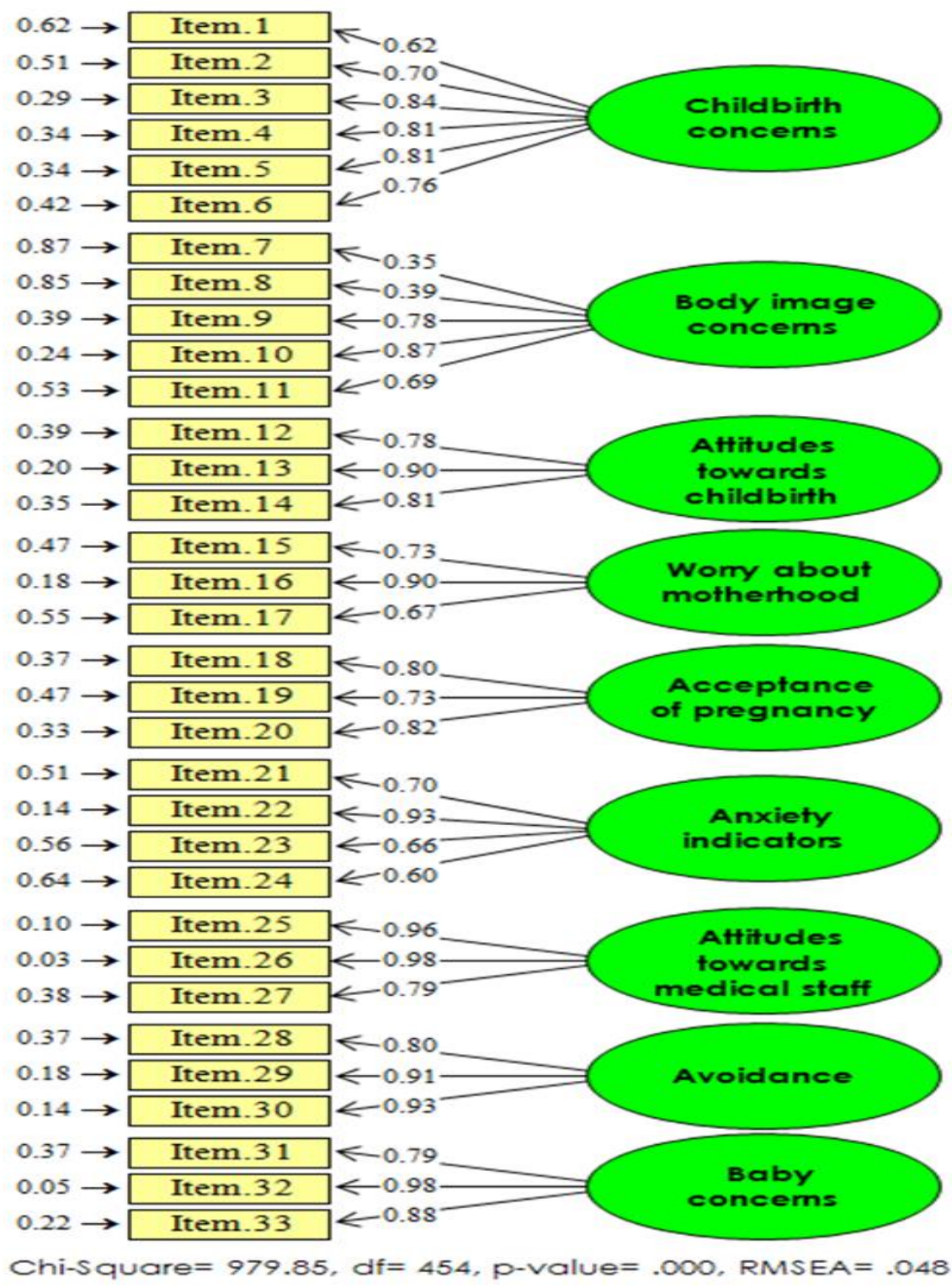

Figure 1. Confirmatory Factor Analysis of the Pregnancy-Related Anxiety Scale: Error Variances and Path Coefficients

For the simultaneous criterion validity of the PregnancyRelated Anxiety Scale, PRAQ-R2 (Derya et al., 2018) was used. In this study, Cronbach's Alpha reliability coefficient of PRAQ-R2 was 0.82 in multiparous pregnant women and 0.86 in primiparous pregnant women. The alpha value of the subscales of the scale for the multiparous and primiparous pregnant women groups were found 0.63 and 0.84 for Fear of giving birth, 0.86 and 0.85 for Worries about bearing a handicapped, and 0.78 and 0.74 for Concern about own appearance, respectively.

The compatibility of the PrAS with the PRAQ-R2 scores for synchronous criterion validity was tested by Pearson correlation analysis. It was determined that there was a positive, strong, statistically significant correlation between the two scale's score (PrAS and PRAQ-R2 scores) of the pregnant women (multiparous pregnant women $\mathrm{r}$ : .60, primiparous pregnant women $\mathrm{r}$ : .65 , $\mathrm{p}<.001$, Fig. 2). As the PrAS scores of the pregnant women increased, their PRAQ-R2 scores also increased Test the construct validity of PrAS that was adapted for the Turkish pregnant women was used CFA. As none of the items has a factor load of less than 0.30 according to CFA results, none of the scale items were omitted [30]. The results were compatible with the CFA results of the original questionnaire [22]. Fit indices were considered to assess whether or not the model constructed with CFA was in accordance with the data. Compatibility was determined for RMSEA, SRMR, CFI, NNFI, AGFI and GFI values in the assessment of the scale (Fig. 1, Table 2).

It was determined that there was a positive, strong and statistically significant correlation between PRAQ-R2 and PrAS scores used to test the reliability of the parallel forms (Fig. 2). 

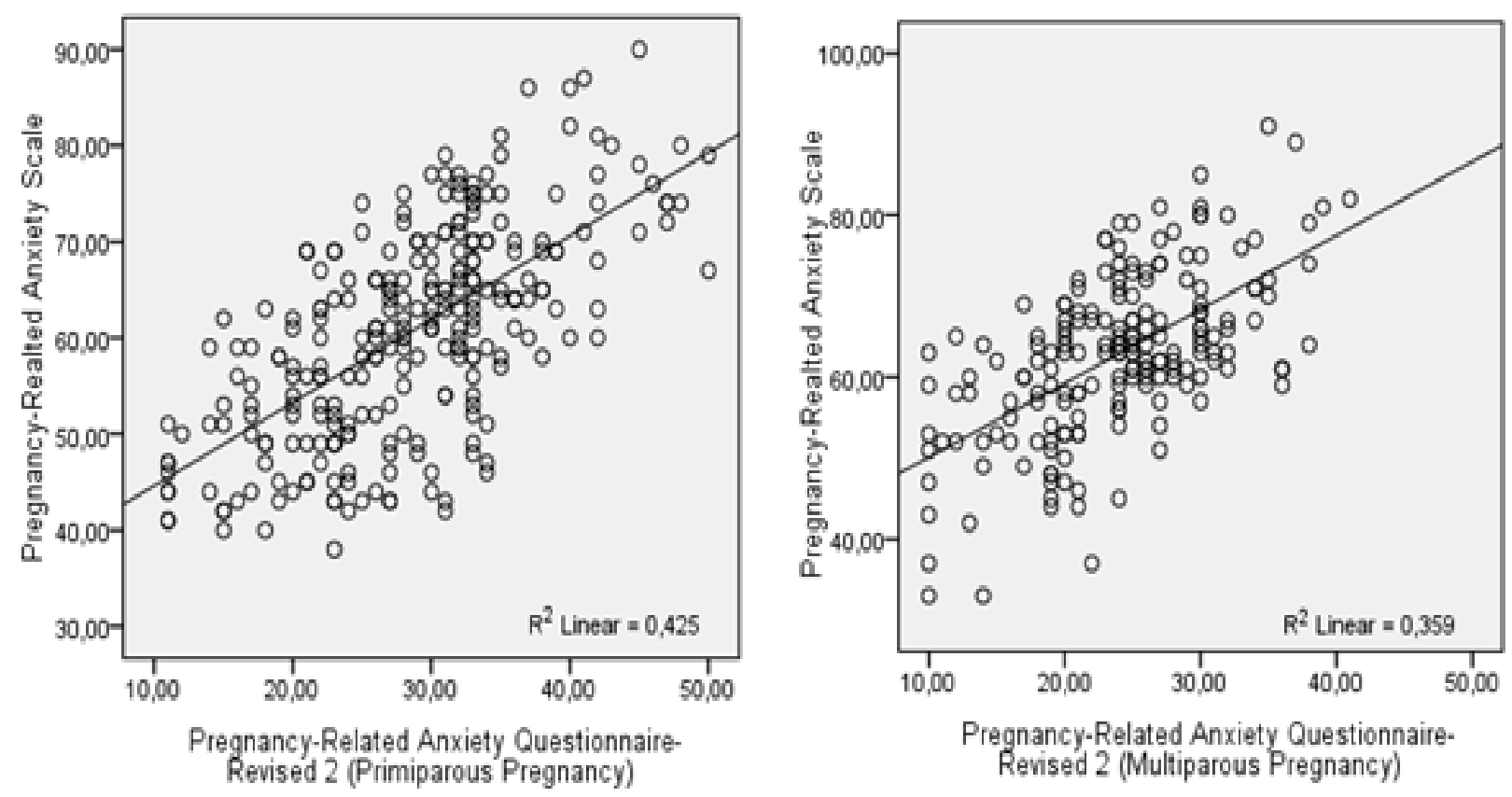

Figure 2. The Correlation of Pregnancy-Related Anxiety Scale Scores and Pregnancy Related Anxiety QuestionnaireRevised 2 Scores

Test the construct validity of PrAS that was adapted for the Turkish pregnant women was used CFA. As none of the items has a factor load of less than 0.30 according to CFA results, none of the scale items were omitted [30]. The results were compatible with the CFA results of the original questionnaire [22]. Fit indices were considered to assess whether or not the model constructed with CFA was in accordance with the data. Compatibility was determined for RMSEA, SRMR, CFI, NNFI, AGFI and GFI values in the assessment of the scale (Fig. 1, Table 2).

It was determined that there was a positive, strong and statistically significant correlation between PRAQ-R2 and PrAS scores used to test the reliability of the parallel forms (Fig. 2).

\subsection{Reliability}

When the item-total score correlations of 33 items included in the scale were examined for the reliability study of Pregnancy-Related Anxiety Scale, it was determined that the correlation coefficient of the items was between 0.27 and 0.57 and it was very highly significant $(\mathrm{p}<.001$, Table 3$)$

When the relationship of the items with the subscale scores was examined, the reliability coefficients were found to be between 0.72 and 0.84 in the subscale of Childbirth Concerns, between 0.55 and 0.83 in the subscale of Body Image Concerns, between 0.87 and 0.91 in the subscale of Attitudes Towards Childbirth, between 0.83 and 0.89 in the subscale of Worry About Motherhood, between 0.77 and 0.81 in the subscale of Acceptance of Pregnancy, between 0.62 and 0.81 in the

subscale of Anxiety Indicators, between 0.90 and 0.96 in the subscale of Attitudes Towards Medical Staff, between 0.90 and 0.93 in the subscale of Avoidance, and between 0.89 and 0.95 in the subscale of Baby Concerns, a positive, statistically very highly significant correlation was found $(\mathrm{p}<.001$, Table 3$)$. Both the total score of the scale items and the reliability coefficient of all the items in the item analyses performed with their own subscale were found to be sufficient.

When the correlations of the subscales of PregnancyRelated Anxiety Scale with the total scale score were examined, it was determined that the reliability coefficients were between 0.31 and 0.67 , positive, statistically very highly significant $(\mathrm{p}<.001$, Table 4$)$

In this study, Cronbach's Alpha reliability coefficient of the PrAS was found to be 0.85 for the overall scale and the alpha value of its subscales was found to be between 0.72 and 0.94 (Table 4).

\section{Discussion}

In the study, the PrAS, developed by Brunton (2018) for application to pregnant women regardless of parity, was adapted for Turkish women. The PrAS is a valid and reliable tool for all Turkish pregnant women

4.1. Validity

Test the construct validity of PrAS that was adapted for the Turkish pregnant women was used CFA. As none of the items has a factor load of less than 0.30 according to CFA results, none of the scale items were omitted [30]. The results were compatible with the CFA results of the original questionnaire [22]. Fit indices were considered to assess whether or not the model constructed with CFA 
Table 3. The Descriptive Statistics of the Items of Pregnancy-Related Anxiety Scale and the Results of the ItemAnalysis (n: 495)

\begin{tabular}{|c|c|c|c|c|c|c|}
\hline \multirow[t]{2}{*}{ Subscales } & \multirow[t]{2}{*}{ Items } & \multirow[b]{2}{*}{$\overline{\mathbf{X}}_{ \pm \mathbf{S D}^{*}}$} & \multicolumn{2}{|c|}{$\begin{array}{l}\text { Item- } \\
\text { Total }\end{array}$} & \multicolumn{2}{|c|}{$\begin{array}{c}\text { Item- } \\
\text { Subscale }\end{array}$} \\
\hline & & & $\mathbf{r}$ & $\mathbf{p}$ & $\mathbf{r}$ & $\mathbf{p}$ \\
\hline \multirow{6}{*}{ 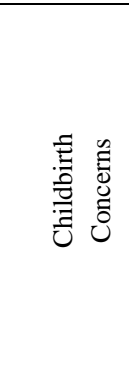 } & $\begin{array}{l}\text { 1. I worry about unnecessary interventions (e.g. } \\
\text { forceps during delivery) }\end{array}$ & $1.86 \pm .73$ & .49 & .000 & .72 & .000 \\
\hline & $\begin{array}{l}\text { 2. I worry that I will tear or need to be cut during } \\
\text { the birth }\end{array}$ & $2.13 \pm .87$ & .49 & .000 & .80 & .000 \\
\hline & 3. I feel afraid of the invasiveness of childbirth & $2.14 \pm .82$ & .56 & .000 & .84 & .000 \\
\hline & $\begin{array}{l}\text { 4. During childbirth, I am worried about being } \\
\text { restrained in some way and not able to move }\end{array}$ & $1.95 \pm .86$ & .55 & .000 & .84 & .000 \\
\hline & 5. I fear I may be harmed during the birth & $2.11 \pm .84$ & .57 & .000 & .84 & .000 \\
\hline & $\begin{array}{l}\text { 6. I fear losing control of my body during } \\
\text { labour }\end{array}$ & $2.04 \pm .84$ & .55 & .000 & .77 & .000 \\
\hline \multirow{5}{*}{ 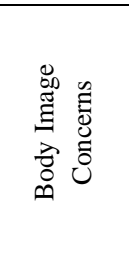 } & 7. I feel good with the way I look. ${ }^{(\mathrm{R})}$ & $2.48 \pm .95$ & .30 & .000 & .55 & .000 \\
\hline & 8. I feel unattractive & $1.77 \pm .72$ & .32 & .000 & .57 & .000 \\
\hline & 9. When I look in the mirror, I feel unhappy & $1.55 \pm .68$ & .48 & .000 & .81 & .000 \\
\hline & $\begin{array}{l}10 . \text { I feel scared that I will never regain my } \\
\text { figure. }\end{array}$ & $1.62 \pm .82$ & .48 & .000 & .83 & .000 \\
\hline & $\begin{array}{l}\text { 11.I worry that my husband/partner doesn't find } \\
\text { me attractive }\end{array}$ & $1.54 \pm .71$ & .40 & .000 & .75 & .000 \\
\hline \multirow{3}{*}{ 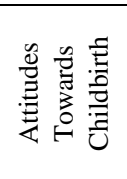 } & 12. I feel prepared for childbirth $^{(\mathrm{R})}$ & $2.67 \pm .86$ & .48 & .000 & .87 & .000 \\
\hline & $\begin{array}{l}\text { 13. When I think of childbirth, I know that I will } \\
\text { cope with pain. }{ }^{(\mathrm{R})}\end{array}$ & $2.69 \pm .85$ & .51 & .000 & .91 & .000 \\
\hline & $\begin{array}{l}\text { 14. I feel confident that I will be fine during } \\
\text { childbirth. }{ }^{(\mathrm{R})}\end{array}$ & $2.74 \pm .87$ & .53 & .000 & .88 & .000 \\
\hline \multirow{3}{*}{ 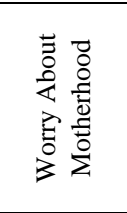 } & $\begin{array}{l}\text { 15. I worry about not knowing what the baby } \\
\text { wants when it cries. }\end{array}$ & $1.58 \pm .73$ & .27 & .000 & .85 & .000 \\
\hline & $\begin{array}{l}\text { 16. I worry that I won't do a good job as a } \\
\text { mother }\end{array}$ & $1.39 \pm .68$ & .31 & .000 & .89 & .000 \\
\hline & $\begin{array}{l}\text { 17. I worry about caring for my baby once I am } \\
\text { home }\end{array}$ & $1.41 \pm .77$ & .34 & .000 & .83 & .000 \\
\hline \multirow{3}{*}{ 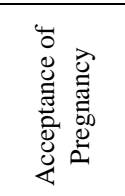 } & 18. I look forward to meeting my baby. ${ }^{(\mathrm{R})}$ & $1.59 \pm .76$ & .38 & .000 & .81 & .000 \\
\hline & 19. This pregnancy is very much wanted $\mathrm{d}^{(\mathrm{R})}$ & $1.71 \pm .83$ & .36 & .000 & .78 & .000 \\
\hline & $\begin{array}{l}\text { 20. My husband/partner and I are very much } \\
\text { looking forward to this baby }{ }^{(\mathrm{R})}\end{array}$ & $1.54 \pm .74$ & .42 & .000 & .77 & .000 \\
\hline \multirow{4}{*}{ 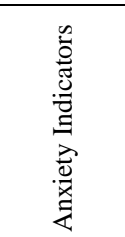 } & 21. Sometimes I feel panicked for no reason & $2.09 \pm .85$ & .41 & .000 & .62 & .000 \\
\hline & 22. At times, my worries seem to snowball & $1.83 \pm .82$ & .51 & .000 & .80 & .000 \\
\hline & 23. My worries interfere with my daily activities & $1.62 \pm .74$ & .48 & .000 & .81 & .000 \\
\hline & 24. I feel content. ${ }^{(\mathrm{R})}$ & $2.41 \pm .91$ & .51 & .000 & .70 & .000 \\
\hline \multirow{3}{*}{ 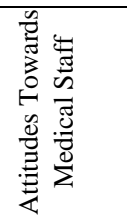 } & $\begin{array}{l}\text { 25. I know the midwives/doctors will be } \\
\text { friendly. }{ }^{(\mathrm{R})}\end{array}$ & $1.72 \pm .75$ & .37 & .000 & .95 & .000 \\
\hline & $\begin{array}{l}\text { 26. I know that midwives/doctors will be kind } \\
\text { and helpful }{ }^{(\mathrm{R})}\end{array}$ & $1.68 \pm .75$ & .36 & .000 & .96 & .000 \\
\hline & $\begin{array}{l}\text { 27. I know that I can ask the midwives/doctors } \\
\text { anything }^{(\mathrm{R})}\end{array}$ & $1.62 \pm .73$ & .31 & .000 & .90 & .000 \\
\hline \multirow{3}{*}{ 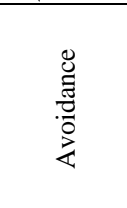 } & $\begin{array}{l}\text { 28. I may consider a caesarian to avoid a vaginal } \\
\text { birth }\end{array}$ & $1.77 \pm 1.02$ & .31 & .000 & .90 & .000 \\
\hline & $\begin{array}{l}29 . \text { I often think a caesarian is better than } \\
\text { vaginal birth }\end{array}$ & $1.60 \pm .97$ & .29 & .000 & .93 & .000 \\
\hline & $\begin{array}{l}\text { 30. I think that caesarian birth is safer than a } \\
\text { vaginal birth }\end{array}$ & $1.58 \pm .94$ & .27 & .000 & .93 & .000 \\
\hline \multirow{3}{*}{ 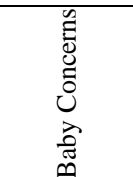 } & $\begin{array}{l}\text { 31. I worry about what I will do if my baby is not } \\
\text { normal }\end{array}$ & $1.76 \pm .86$ & .33 & .000 & .89 & .000 \\
\hline & 32. I worry about having a sick or disabled baby & $1.71 \pm .89$ & .38 & .000 & .95 & .000 \\
\hline & $\begin{array}{l}\text { 33. I constantly worry that something will be } \\
\text { physically wrong with my baby }\end{array}$ & $1.61 \pm .85$ & .40 & .000 & .92 & .000 \\
\hline
\end{tabular}

*The score interval of the items is $1-4$, the score interval obtained is $1-4$ 
Table 4. Correlations of Pregnancy-Related Anxiety Scale Subscale Scores with Total Scale Score (n: 495)

\begin{tabular}{|c|c|c|c|}
\hline Scale Subscales & $\begin{array}{r}\text { Subscale- } \\
\text { r }\end{array}$ & $\begin{array}{l}\text { elationship } \\
\text { p }\end{array}$ & Cronbach $\alpha$ \\
\hline 1.Childbirth Concerns & .67 & .000 & .89 \\
\hline 2.Body Image Concerns & .56 & .000 & .72 \\
\hline 3.Attitudes Towards Childbirth & .57 & .000 & .86 \\
\hline 4. Worry About Motherhood & .36 & .000 & .81 \\
\hline 5.Acceptance of Pregnancy & .58 & .000 & .82 \\
\hline 6.Anxiety Indicators & .66 & .000 & .74 \\
\hline 7. Attitudes Towards Medical Staff & .37 & .000 & .93 \\
\hline 8.Avoidance & .31 & .000 & .91 \\
\hline 9.Baby Concerns & .40 & .000 & .91 \\
\hline Total Scale & & & .85 \\
\hline
\end{tabular}

was in accordance with the data. Compatibility was determined for RMSEA, SRMR, CFI, NNFI, AGFI and GFI values in the assessment of the scale (Fig. 1, Table 2).

It was determined that there was a positive, strong and statistically significant correlation between PRAQ-R2 and PrAS scores used to test the reliability of the parallel forms (Fig. 2).

4.2. Reliability

The reliability of the PrAS was evaluated with item-total correlation, parallel form and alpha internal consistency coefficient reliability.

Cronbach's Alpha internal consistency coefficients of the Pregnant women were found as follows: .89 in the subscale of Childbirth Concerns, .72 in the subscale of Body Image Concerns, .86 in the subscale of Attitudes Towards Childbirth, .80 in the subscale of Worry About Motherhood, .82 in the subscale of Acceptance of Pregnancy, .74 in the subscale of Anxiety indicators, .93 in the subscale of Attitudes Towards Medical Staff, .91 in the subscale of Avoidance, and 0.91 in the subscale of Baby Concerns (Table 4). Alpha internal consistency coefficient for a measuring tool should be as close to 1 as possible [33,34]. The internal consistency coefficients obtained for the PrAS were highly reliable. The PrAS's subdimensions were highly reliable $(\mathrm{p}=.001)$. Results are compatible with original questionnaire results [22].

This study, the item-total correlation coefficients (.27 to .57) were above the acceptable value for item selection $(\geq .20)$ (Table 3). The high correlation coefficient obtained for each of the items demonstrates that the items are efficient and adequate in measuring the intended behavior [34]. The correlation between each item's score and the total score was statistically significant and acceptable for the groups included in the study $(\mathrm{p}=.001)$. The findings are similar to the item-total correlation coefficient results of the original questionnaire $(.27$ and .57) [22].

The study demonstrated that, the Turkish version of the PrAS is a valid and reliable tool for pregnant women. The strengths of the study: it was tested whether or not it was a suitable assessment instrument to determine the pregnancy-related anxiety in all pregnant women, regardless of parity. The diagnosis of the anxiety level in pregnant women has clinical importance. The study limitations: the reliability and validity of the scale were not tested pregnant women with high risk.

\section{Conclusion}

The results were compatible with results of the original scale. CFA results were similar to the original scale results. Alpha internal consistency coefficient, item-total correlation, the parallel form reliability of the scale were high. The Turkish version of the PrAS had good conformity with the original PrAS. The PrAS in Turkish version is a valid and reliable instrument to assess the pregnancy-related anxiety level.

In addition, it is considered that this scale may be a useful instrument to obtain a more comprehensive picture of the anxiety experienced by Turkish pregnant women and apply the target-specific clinical interventions. Using the PrAS may contribute to the early diagnosis, treatment, and management of the pregnant-related anxiety.

\section{Ethical Considerations}

Before starting the study, Robyn Brunton was communicated via Internet and Robyn's written consent was obtained to conduct the reliability and validity study 
of the Turkish version. The author sent the required data on her scale and its stages to the researchers via e-mail. The approval (Reference no:10840098-604.01.01E.52518/689) from the Ethics Committee of the relevant university and institutional permission was obtained in order to conduct the study on the pregnant women. Before collecting data, the pregnant women were informed about the study and their written consent was received.

\section{Referances}

1. Nicholson, W.K, Setse, R, Hill-Briggs, F, Cooper, L.A, Strobino, D, Powe, N.R, Depressive symptoms and health-related quality of life in early pregnancy, Obstetrics \& Gynecology, 2006, 107, 798-806.

2. Brunton, R.J, Dryer, R, Saliba, A, Kohlhoff, J, Pregnancy anxiety: A systematic review of current scales, Journal Of Affective Disorders, 2015, 176, 24-34.

3. Bayrampour, H, Ali, E, McNeil, D.A, Benzies, K, MacQueen, G Tough, S, Pregnancy-related anxiety: a concept analysis, International Journal of Nursing Studies, 2016, 55, 115-130.

4. Van Bussel, J.C, Spitz, B, Demyttenaere, K, Anxiety in pregnant and postpartum women. An exploratory study of the role of maternal orientations, Journal of Affective Disorders, 2009, 114, 232-242.

5. Dubber, S, Reck, C, Müller, M, Gawlik, S, Postpartum bonding: the role of perinatal depression, anxiety and maternal-fetal bonding during pregnancy, Archives of Women's Mental Health, 2015,18(2), 187-195.

6. Dennis, C.L, Falah-Hassani, K, Shiri, R, Prevalence of antenatal and postnatal anxiety: a systematic review and meta-analysis, The British Journal of Psychiatry, 2017, 210(5), 315-323.

7. Huizink, A.C, Delforterie, M.J, Scheinin, N.M, Tolvanen, M, Karlsson, L, Karlsson, H, Adaption of pregnancy anxiety questionnaire-revised for all pregnant women regardless of parity: PRAQ-R2, Archives of Women's Mental Health, 2016 , 19, 125-132.

8. Hassani, K.F, Shiri, R, Dennis, C.L, The prevalence of antenatal and postnatal co-morbid anxiety and depression: A metaanalysis, Psychological Medicine, 2017, 47(12), 2041-2053.

9. World Health Organization Report, Maternal Mental Health and Child Health and Development in Low and Middle Income Countries: Report of Meeting held in, 2008, Geneva, Switzerland; Available from: http://www.who.int

10. Bann, C.M, Parker, C.B, Grobman, W.A, Willinger, M, Simhan, H.N, Wing, D.A, Wapner, R.J, Psychometric properties of stress and anxiety measures among nulliparous women, Journal of Psychosomatic Obstetrics \& Gynecolog, 2017, 38, 53-62.

11. Madhavanprabhakaran, G.K, D’Souza, M.S, Nairy, K.S, Prevalence of pregnancy anxiety and associated factors, International Journal of Africa Nursing Sciences, 2015, 3, 1-7.

12. Ahluwalia, I.B, Mack, K.A, Mokdad, A, Mental and physical distress and high-risk behaviors among reproductive-age women, Obstetric. Gynecology, 2014, 104 (3), 477-483.

13. Littleton, H.L, Breitkopf, C.R, Berenson, A.B, Correlates of anxiety symptoms during pregnancy and association with perinatal outcomes: a meta-analysis, American Journal of Obstetric Gynecology, 2007, 196 (5), 424-432.

14. Skouteris, H, Wertheim, E.H, Rallis, S, Milgrom, J, Paxton, S.J, Depression and anxiety through pregnancy and the early postpartum: an examination of prospective relationships, Journal of Affective Disordoer, 2009, 113 (3), 303-308.

15. Bonari, L, Pinto, N, Ahn, E, Einarson, A, Steiner, M, Koren, G, Perinatal risks of untreated depression during pregnancy, Can $J$ Psychiatry, 2004, 49(11), 726-735.

16. Grote, N.K, Bridge, J.A, Gavin, A.R, Melville, J.L, Iyengar, S, Katon, W.J, A meta-analysis of depression during pregnancy and the risk of preterm birth, low birth weight, and intrauterine growth restriction, Archives of General Psychiatry,2010,67(10),1012-1024. doi:10.1001/ archgenpsychiatry.2010.111

17. Grigoriadis, S, Vonder Porten, E.H, Mamisashvili, L, Tomlinson, G, Dennis, C.L, Koren, G, The impact of maternal depression during pregnancy on perinatal outcomes: a systematic review and meta-analysis, Journal of Clinical Psychiatry, 2013, 74(4), e321-e341.

18. Van Willenswaard, K.C, Lynn, F, McNeill, J, McQueen, K, Dennis, C.L, Lobel, M, Alderdice, F, Music interventions to reduce stress and anxiety in pregnancy: a systematic review and meta-analysis, BMC Psychiatry, 2017, 17(1), 271.

19. Askarizadeh, G, Karamoozian, M, Darekordi, A, Validation of Iranian version of pregnancy related anxiety questionnaire, International Journal of Preventive Medicine, 2017, 8, 17-23

20. Goodman, J.H, Tyer-Viola, L, Detection, treatment, and referra of perinatal depression and anxiety by obstetrical providers, Journal of Womens Health (Larchmt), 2010, 19, 477-90.

21. Koelewijn, J.M, Sluijs, A.M, Vrijkotte, T.G, Possible relationship between general and pregnancy-related anxiety during the first half of pregnancy and the birth process: a prospective cohort study, BMJ open, 2017, 7, 1-13. e013413

22. Brunton, R.J, Dryer, R, Saliba, A, Kohlhoff, J, The initial development and validation of the pregnancy-related anxiety scale, Women and Birth, 2018, 32(1), e118-e130.

23. Erdoğan, S, Nahcivan, N, Esin, M.H, Hemsirelikte Arastırma Süreç, Uygulama ve Kritik. 3.Bask1. Istanbul: Nobel Tıp Kitapevleri; 2018

24. Gözüm, S, Aksayan, S, Kültürlerarası ölçek uyarlaması için rehber II: psikometri özellikler ve kültürlerarası karşılaştırma, Hemsirelikte Araștırma Geliștirme Dergisi, 2003, 5, 3-14.

25. Derya, Y.A, Taşhan, S.T, Duman, M, Ozan, Y.D, Turkish adaptation of the pregnancy-related anxiety questionnairerevised 2: Validity and reliability study in multiparous and primiparous pregnancy, Midwifery, 2018, 62, 61-68.

26. Wennman-Larsen, A, Tishelman, C, Wengström, Y, Gustavsson, $\mathrm{P}$, Factors influencing agreement in symptom ratings by lung cancer patients and their significant others, Journal of Pain and Symptom Management, 2007, 33(2), 146-155.

27. Brislin, R.W, Back-translation for cross-cultural research, Journal of Cross-Cultural Psychology, 1970, 1(3), 185-216.

28. Chapman, D.W, Carter, J.F, Translation procedures for the crosscultural use of measurement instruments, Educational Evaluation and Policy Analysis, 1974, 1(3), 71-76.

29. Aksakoğlu, G, Sağlıkta Araştırma ve Çözümleme. Üçüncü Yazım. İzmir: Meta Basım Matbaacılık Hizmetleri, 2013.

30. Büyüköztürk, Ş, Faktör analizi: Temel kavramlar ve ölçek geliștirmede kullanımı, Kuram ve Uygulamada Eğitim Yönetimi,.2002, 32, 470-483.

31. Donna, H, Confirmatory Factor Analysis, Newyork: Oxford University Press, 2009.

32. Şimşek, Ö.F, Yapısal Eşitlik Modellemesine Giriş Temel İlkeler ve LISREL Uygulamaları, Ankara: Cem Web Ofset; 2007.

33. Bland, J.M, Altman, D.G, Statistic Notes: Cronbach's alpha, BMJ: British Medical Journal, 1997, 314, 572.

34. Bowling, A, Ebrahim, S, Handbook of health research methods: investigation, measurement and analysis, McGraw-Hill Education (UK), 2005.

35. George, D, Mallery, M, SPSS for Windows Step by Step: A Simple Guide and Reference, 17.0 update (10a ed.) Boston: Pearson; 2010.

http://edergi.cbu.edu.tr/ojs/index.php/cbusbed isimli yazarın CBU-SBED başlıklı eseri bu Creative Commons Alınt1-Gayriticari4.0 Uluslararas1 Lisansı ile lisanslanmıştır.

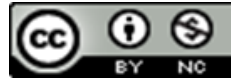

